\title{
Twelve Hundred Charts at a Third of a Cent
}

\author{
A Few Words About a Necessary Expenditure for Which Congress Has Failed to Provide \\ By C. H. Claudy
}

W HETHER the purpose of a navy is to fight or to Wrevent a fight may be open to discussion. But it is not open to discussion, whether a navy which has to stay at home can either fight or prevent a fight in foreign waters.

A navy is composed largely of ships. The ships carr guns and the guns must have ammunition and men to man, aim and fire them. But all the ships and all the guns and all the ammunition and all the men our navy possesses could not be applied to any war or warprevention purpose, if the ships could not carry the guns and men and ammunition to the place where the trouble was or was to be prevented.

A ship cannot go in unknown waters without a chart, except at the risk of its total loss. A lost ship cannot fight or prevent a fight. It is evident, then, that as between a warship without charts or no ship at all, there is little choice, so far as action is concerned.

The United States has three sources of charts. One is the Hydrographic Office of the Navy. The second is the Coast and Geodetic Survey that maritime interests willingly take the risk of sending vessels into these uncharted waters, rather than forego the profits of such voyages. Of course some one pays the bill of lost or damaged ships; and that some one in this case is the American people who are hardly in a position to realize that one lost ship is more expensive than all the charts necessary to give her a safe voyage.

It is to many unthinkable that this country should ever have a serious difference of opinion with Great Britain. To most thinking Americans it is equally difficult to believe that any discussions we may have with Japan or Russia or the Fiji Islands or China should require a war to decide.

But wars have happened, and we have fought them. And if, for any reason, Great Britain happened to b neutral in such a discussion in which we took a leading part, or if she, for any reason, felt it inadvisable t.) continue the present cordial and friendly relations which exist between her and our Hydrographic Office,
Admiralty charts. To obtain these plates from the existing charts will require, with the present printing plant of the Hydrographic Office, five years of time and the ridiculously small appropriation of sixty thousand dollars a year-a total of three hundred thousand dollars. This amounts to something less than a third of a cent, spread over five years, for each one of our hundred and eight millions. If the three hundred thousand dollars is not forthcoming at the present rate of progress, it will require forty years to become independent of Great Britain for charts.

The amount needed is so small, and the object to be gained so large that it would seem almost unbelievable that Congress should hesitate for a moment to appro. priate it. But the gentlemen who make the laws ar not naval men, many of them never saw a battleship or a chart, and have no knowledge of the relations of one to the other. A very able American once brought a large amount of ridicule upon himself by his oratorical reference to the million men who would "spring to arms overnight" in the event of an emergency. The

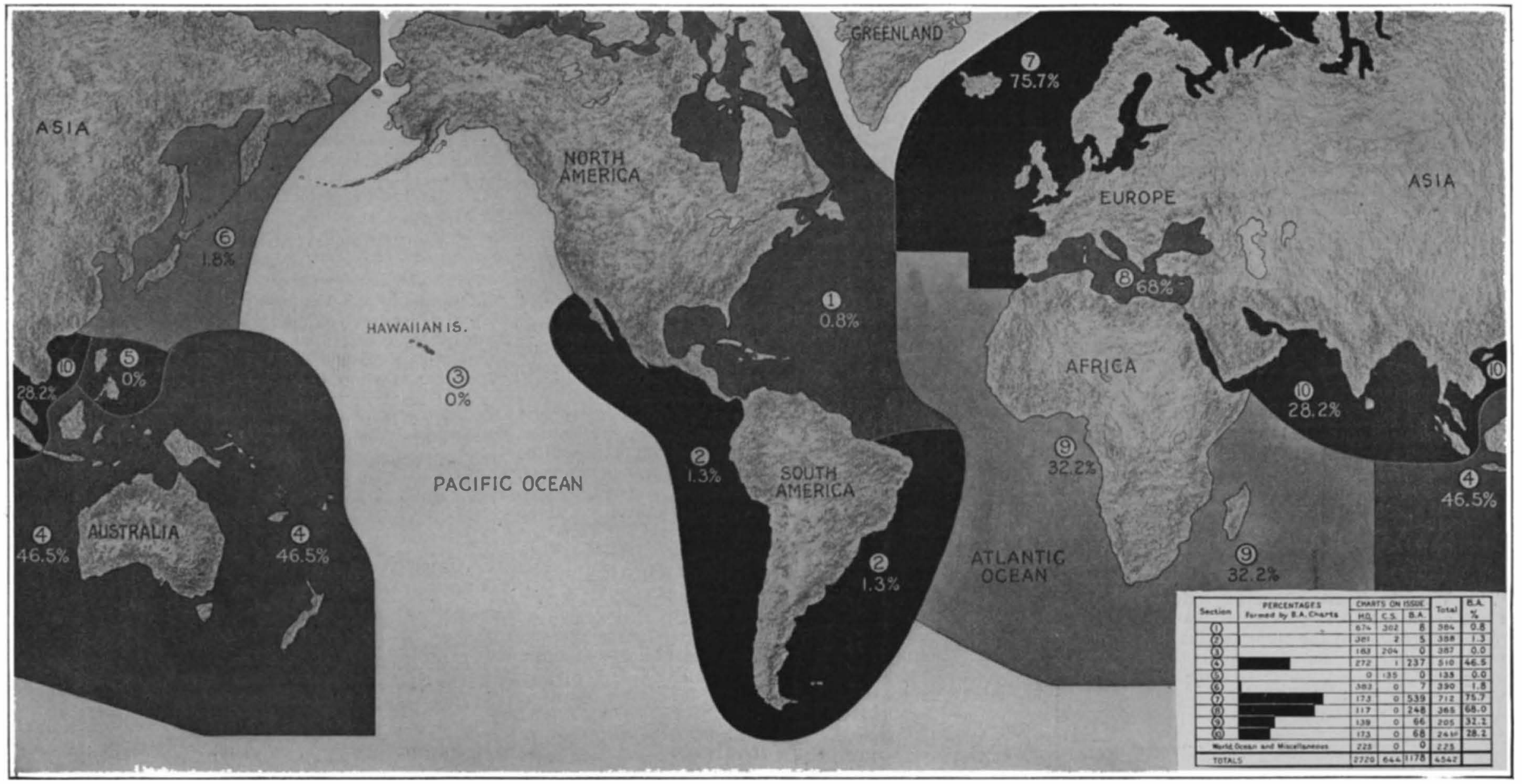

Admiralty charts to the entire chart outfit required by the American navy. In the tabular insert the same information is given somewhat more fully, the three columns indicating the nurnber of issued charts from each of the three sources-

U. S. Hydrographic Office, U. S. Coast Survey, and British Admiralty

Where the charts come from on which our Navy depends

the world's supply of charts, as issued by foreign hydrographers. Of these, the British Admiralty is the largest and most important source.

Between Great Britain and the United States there exist the most cordial and friendly relations hydrographically. IVe use the British charts and they use graphically. We use curs. We take their charts, cony them, add to them. our charts. The world is a big place to go over with a sounding line, and the less such work has to be duplicated the more can be done. It is not only the navy which uses charts, but each and every ship that floats. The more charts, the better charts, the more easily accessible charts, the more ships can go to the more places and the less is the loss incidental to commerce.

At the present moment, the charts of Alaskan waters are sadly incomplete. Alaska has an enormous coast line, much of which is either uncharted or but little charted. Yet so great is the shipping need, and so far has commerce outrun charting in these waters of having a navy which couldn't go abroad for our interests, because we had not the charts which would enable us to go.

During the war the United States ordered charts from Great Britain in large numbers. Most of them were received; one in lare n thous were received; one case of average, three , often longer: and even then, if we were to reproduce them, the time would be greatly extended. So that if we had another war with any power in any part of the world, we would still be dependent upon our own supplies, or have to face the need of waiting until British charts could be obtained. It is not so much a question of being dependent upon Great Britain's good will as upon being dependent upon the natural limitations of time to manufacture, and to ship. And a war does not wait for a belligerent to get ready; it strikes as suddenly and with the opponent as much unprepared as possible.

At the present time the Hydrographic Office is twelve hundred plates behind a complete stock of British ridicule came, not from the thought of the patriotism of our soung manhood, but from the fact that the possessed no arms to which to spring. In the event of trouble to be started or stopped, the navy has ships and hundred charts overnight, or over a year's time.

Some critic may observe "But why doesn't the $\mathrm{Hy}$ lrographic Office pick out the important charts and cony them now out of its current funds?" To which the reply must be made that if any one of us all is a competent picker of the "important chart" he ought not to conceal his light under a binnacle but come right to Washington and pick.

The United States is dependent upon Great Britain for more than 75 per cent of the charts it may require for all the north and west coasts of Europe, for 46.5 per cent of the charts it needs of a very important part of the coast of Asia, and for various lesser percentages for charts in the rest of the world. For the whole world of charts, the United States must depend upon Continued on page $27 \%$ ) 


\section{UNISOL \\ Rez. U. S. Pat. Off. \\ Assures Successful Boiler Operation \\ SCALE SAMPLES PROVE: That Excessive scale accumulation, in many cases, results from sources entirely un- suspected. Each type of scale invari- ably indicates that certain definite treatment is required, To Effect Suc- cessful Boiler Operation. \\ We Guarantee: That UNISOL will gradu- lly remove boiler scale, prevent scale forma- tion, stop and prevent corrosion and We shall be pleased to make every 'effort
to assist those who wish to maintain ideal
operating conditions. \\ Pamphlet on request
Money back guarantee \\ UNISOL MFG. CO., Jersey City, N. J.}

For Gunsmiths, Tool Makers, Experimental \& Repair Work, etc.

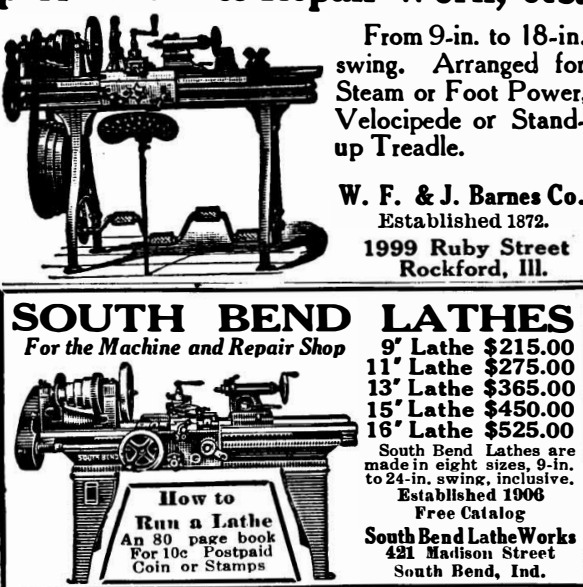

\section{ASBESTOS}

We are miners and shippers of Crude Asbestos in any quantity. We produce all grades at our world famous
BELL ASBESTOS MINES in Canada. We also carry fibres, spin yarns,

For anything you want in Asbestos, turn to KEASBEY \& MATTISON COMPANY AMBLR DEPT. S-1

AMBLER, PENNA., U. S. A.

C. MACHINES Corliss Engines, Brewers UL The VILTER MFG. CO. The VILTER MFG. CO.
Milwauke, Wis. We Wil Make It Anything in a metal stamping or novelty pru-
dured from any metal and finished in any colvr.
Waterbury Button Co.. Waterbury, Conn. Experimental and Model Work Fino Instruments and Fine Machlnery,

Speelal Tuols, Dies, Gear Cutting, Ete.
HENRY ZUHR, 489-93 Broome St., New York City

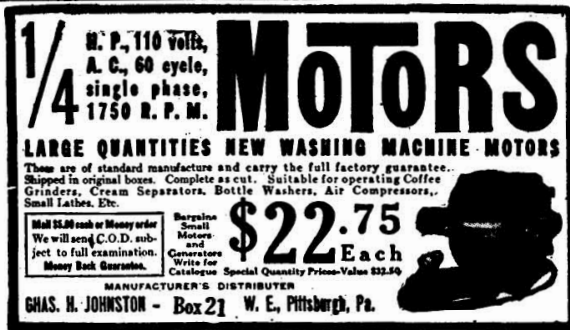

Weber Crank-Pin Re-Turning Tool

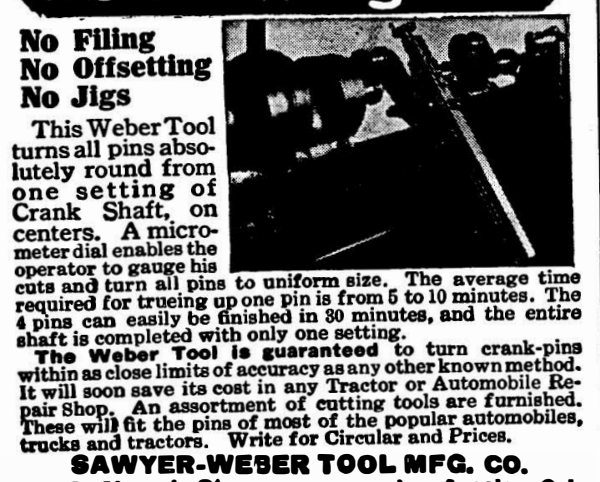

SAWYER-WEBER TOOL MFG. CO.
Twelve Hundred Charts at a Third of a Cent

(Continued from page 264)

Great Britain for more than twenty-five per cent of its charts.

In November, 1914, the following notice was sent out from the British Admiralty chart agent

"I am instructed to give notice that no supplies of Admiralty charts are to be made without authority to any European countries, or subject of these countries, with the exception of France, Russia, Greece and Portugal. Applications for charts from all other parts of the world are to be submitted for consideration Further, no sales are to be allowed to any customer until the bona fides of the purchaser has been satisfactorily proved and a certificate stating the name of customer, nationality, service, and ship or

shipping company, for which the charts are required, has been received."

Suppose the date to be 1921 instead of 1914. Suppose, instead of being an ally of England, England stood aloof, and sold charts neither to us nor to the Fiji Islands if we were at war with them? It will not do to say that we have copies of all charts Great Britain has issued. So we have. But we have not enough Charts wear out quickly in use. For every ship there must be a full outfit of charts for every locality she can possibly need to visit.

From the standpoint of economy, it is far cheaper for us to reproduce a chart and sell it at cost, than to buy it from Great Britain. But this is not a matter of economy. Whether we spend a hundred thousand dollars in ten years buying charts from Great Britain for naval use or three hundred thousand in five years reproducing those charts so that we are forever independent of Great Britain-and of the items of time of transportation and time of manufacture-is not important from the dollar side. It is vitally importhe from the naval efficiency side.

The war taught us something of what unpreparedness meant. It gave to us all the full knowledge of how useless wer guns without men, men without clothes and food, clothes and food for men abroad without ships to carry them. In any war not fought at home, the vital factor, the underlying, dominant thing by which a und lor And transportation at sea is either a leap in the chartless dark or a reasonable hazard if the ship has the knowledge of reef, shoal, current, depth, bottom, lights, buoys, which can be obtained from charts and only from charts.

We have the most able chart makers in the world. We have a navy which is second to none in quality and second to but one in size. We have the money, the men, the will, to be invincible in defense. Are we to and all that to stultify all that we are, charts? Or will we who do not go down to the sea in ships, but who have both a wholesome admiration for, and an utter reliance upon, our navy, see to it that our legislative body does not deny this necessary expansion to our naval munitions program?

When Humpty-Dumpty Travels (Continued from page 265)

or a quarter-sized honeycomb for the bottom layer as a cushion. If these becom only slightly damp they collapse and are useless.

The express company now requires that pads of excelsior be used on top of and beneath the half-cases of eggs as a buffer. It is recommended that a third pad be placed between the two top layers of eggs, as these are most often broken.

It is a well-known fact that even a strong man cannot crush an egg if he applies his strength evenly on the ends But it does not take much strength to crush an egg if pressed on the side. The best of the new egg containers take ad-

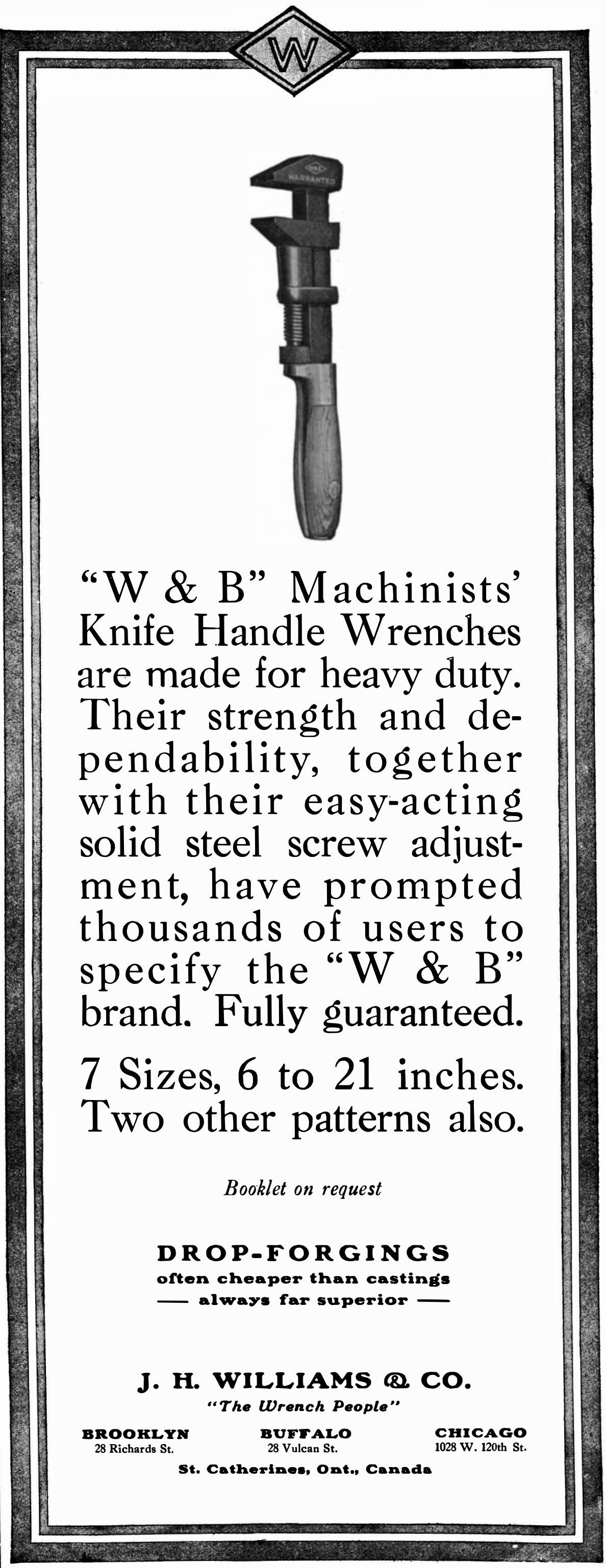

